University of Massachusetts Amherst ScholarWorks@UMass Amherst

Jul 27th, 2:00 PM - 3:00 PM

\title{
Marketing strategy to increase exhibition attendance through controlling and eliminating leisure constraints
}

Daehui Lee

Soonchunhyang University, junimaneso@hanmail.net

Radesh Palakurthi

Drexel University,rp453@drexel.edu

Lee, Daehui and Palakurthi, Radesh, "Marketing strategy to increase exhibition attendance through controlling and eliminating leisure constraints" (2011). International CHRIE Conference-Refereed Track. 6.

https://scholarworks.umass.edu/refereed/ICHRIE_2011/Wednesday/6

This Empirical Refereed Paper is brought to you for free and open access by the Hospitality \& Tourism Management at ScholarWorks@UMass Amherst. It has been accepted for inclusion in International CHRIE Conference-Refereed Track by an authorized editor of ScholarWorks@UMass Amherst. For more information, please contact scholarworks@library.umass.edu. 
Marketing Strategy te Ingrease Exhibition Attendance through hentrolling and Eliminating Leisure Constraints

\section{ABSTRACT}

The purpose of this study is to discover marketing strategies to increase exhibition attendance through controlling and eliminating leisure constraints which prevent customers from attending exhibitions. The results showed that there were significant relationships between demographic characteristics of exhibition attendees and the leisure constraints (i.e., intrapersonal constraints, interpersonal constraints, and structural constraints) perceived by them. The findings of this study give exhibition planners, organizers, managers, and researchers, useful information for discovering marketing strategies in order to control and eliminate specific constraints which prevent customers from attending exhibitions.

Keywords: Exhibition; Leisure Constraints Theory; Marketing strategy

\section{INTRODUCTION}

In past decades, the exhibition industry has been performing an important economic function in attracting huge numbers of people whose purpose is to share updated information and knowledge, to buy or sell products and services, to launch new products, and to negotiate contracts and deals (Rogers, 2003). McCabe (2001) found that the exhibition industry also provides various business opportunities with the "potential" to accelerate contracts and promotions. Bonoma (1983) described the potential of exhibitions as an effective and efficient marketing pathway not only to announce new products, provide new information, and introduce new technology, but also to interact and communicate with people face-to-face. Thus, Blythe (2002) stated that exhibitions are regarded as a tactical marketing technique to achieve a firm's business aim and to enhance communications with existing and potential customers. As domestic and international exhibitions have become greater in numbers, 
customers have shown strongerintentiens gf farticinating in exhibitions (Rice \& Almossawi, 2002; Smith, Hama, \& Smith, 2003). The main reasons that customers attend exhibitions are to acquire new information or knowledge, and to enjoy the interesting and exciting programs and performances (Robbe, 2000). Customers also wish to take part in exhibitions because they are interested in the various displays presented at the exhibitions (Kim, Sun, \& Ap, 2008).

Interesting activities and low entrance fees motivate customers to attend exhibitions. However, many people may envision an exhibition as simply a quiet place where new products are displayed. Luckhurst (1951) defined an exhibition as not only an event that displays a collection of new products but also as an event that provides exciting human activities, performances, entertainment, and other dynamic activities for the exclusive purpose of achieving the marketing goals of companies. Kotler (1971) explained that marketing is not the art of discovering intelligent ways of disposing the products of firms but the art of generating authentic customer value. Luckhurst (1951) and Kotler (1971) commonly emphasized that marketing should be designed with special features which will draw customers' attention. Kotler and Levy (1969) noted that marketing is a pervasive societal activity that goes considerably beyond the selling of products alone. They asserted that the nature of marketing function is to increase product sales by improving communication with customers. Lee (2007) indicated that exhibitions and marketing have a common objective - to enhance sales through improved promotions, business interactions, and human activities.

To encourage more customers to attend exhibitions, it is important to understand the desires of the customers before participating in exhibitions since a large number of customers attending exhibitions is the key factor in evaluating the success of exhibitions (Ling-Yee, 2006). However, no research has been conducted to investigate the constraints which prevent customers from attending exhibitions or the relationships between exhibition participation 
and such constraints. Lee and Palakurthi: Marketing strategy to increase exhibition attendance

A better understanding of the tangible and intangible constraints of exhibition participation also has great theoretical and practical value for the development of the exhibition industry. Eliminating major constraints is an effective way to increase customer participation in exhibitions. In addition, the findings of this research may suggest efficient promotional strategies for exhibition managers and organizers. Therefore, it is necessary to investigate the constraints for exhibition participation with a new perspective on leisure. The purpose of this study is to discover marketing strategies to increase exhibition attendance through controlling and eliminating leisure constraints which prevent customers from participating in exhibitions.

The objective of this study is to examine a significant difference in the mean scores for the degree of leisure constraints according to demographic profile (i.e., age, marital status, education, and place of residence).

\section{LITERATURE REVIEW}

This chapter presents the literature related to the exhibition industry and Leisure Constraints Theory.

\subsection{The exhibition industry}

Morrow (2001) described an exhibition as an impermanent and time-sensitive marketing event organized by an individual or corporation, where buyers and sellers interact with each other in order not only to purchase products and services but also to achieve marketing goals, either at the time of presentation or at a future date. Konikow (1986) indicated that exhibitions are events for marketing opportunities, stimulating the interests of customers for business, and targeting specific markets through personal contact and interaction. Bello (1992) and Blythe (2002) noted that exhibitions offer marketers a unique 


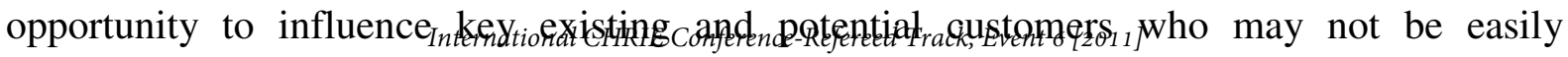
reachable through field sales and other promotional methods.

The economic impact of the exhibition industry is much greater than other marketing efforts made by companies (Kim, Chon, \& Chung 2003; Yoo \& Weber, 2005). The exhibition industry has a huge economic and social impact on business for the following reasons. First, exhibitions are commercial in nature as deals between sellers and buyers are frequently made during exhibitions. Second, exhibitions invite representatives from a range of interrelated industries in order to generate extensive economic effects (Kim, Sun, \& Ap, 2008). Thus, many researchers have surmised that exhibitions are highly beneficial to companies and offer a unique marketing medium that customers can use (Kaminer, 1992; Rosson \& Seringhaus, 1995). Furthermore, Ling-Yee (2007) emphasized the importance of exhibitions as a means for developing and improving channel relationships for improving the effectiveness of marketing effort. Exhibitions are seen as an important opportunity for companies to establish, develop, defend or extend their position within the network (Rosson \& Seringhaus, 1995). This indicates that a firm's participation in exhibitions can be an opportunity to develop the most useful contacts and conduct purchases in a complementary way (Barreyre \& Letrein, 1990; Blythe, 2002).

In order for the exhibition industry to flourish more effectively, previous studies in industrial marketing management recommend that exhibition managers should develop a specific plan to meet marketing objectives prior to the exhibition (Godar \& O'Connor, 2001). In addition, managers should select the right exhibitions to match the right types of buyers with their products (Kijewski, Yoon, \& Young, 1993; Shoham, 1992), as well as coordinate pre-exhibition, at-exhibition, and post-exhibition efforts to initiate and build relationships with key accounts (Blythe, 2002). Lastly, exhibition managers should evaluate exhibitions to make the budget payoff (Herbig, O'Hara, \& Palumbo, 1994; Lilien, 1983). However, https://scholarworks.umass.edu/refereed/ICHRIE_2011/Wednesday/6 


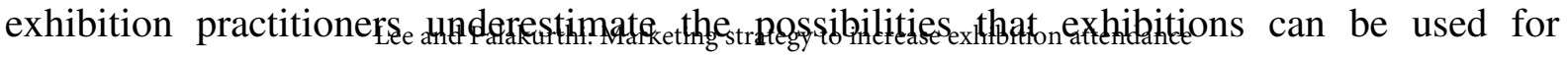
providing leisure activity opportunities for attendees. Even though exhibitions offer valuable opportunities for leisure activities, people normally consider exhibitions as a business interaction environment or a place where pictures, sculptures and other objects are displayed for observation and appreciation. Luckhurst (1951) insists that exhibitions should include exciting human activities and entertaining events in order to increase not only business interactions but also human interactions. Through transforming exhibition features, modern exhibitions provide various opportunities for customers to interact with each other not only to share information, technology, and products, but also to experience leisure activities (McLean, 1994).

Exhibitions are usually regarded as effective promotional settings for business people and customers to interact. In the modern exhibition industry, the attributes of exhibitions have transformed in varied ways. For example, an exhibition maintains its original features including displays of products, advertisements of companies, and other business communication, while adding entertaining facilities, exciting performances and experiences, as well as leisure activities (Lee, 2007). An exhibition center is no longer used only for smallscale social and economic transactions. Its functional and operational range has extended to upscale social and economic mega-events and festivals. Thus, exhibitions have noticeable features to promote sales, enhance human activities, encourage entertainment, and improve leisure activities.

\subsection{Leisure Constraints Theory}

Research on leisure constraints has continuously been conducted since the 1950s, identifying constraints in leisure participation activities (Reeder \& Linkowski, 1976; Thomas, 1956; Witt \& Goodale, 1981; Wood, 1971). Leisure constraints have become a distinctive sub-field of leisure studies while a coherent body of literature has gradually changed and 


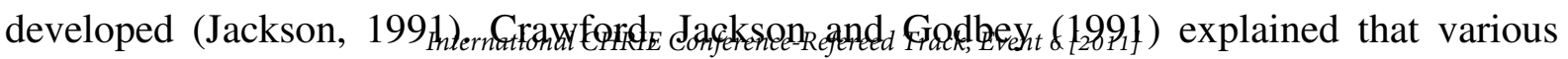
constraints could exist in leisure and those constraints prevented leisure attendees from being involved in activities even though they are willing to join. Such impediments are called “leisure constraints."

Early researchers of leisure constraints raised the issue of barriers to recreation activity participation (Searle \& Jackson, 1985). The word barriers tends to point researchers' attention in the direction of only one type of constraint, which intervenes between preference and participation (Crawford \& Godbey, 1987). However, a much more comprehensive and complex range of constraints is now recognized than was previously the case when barriers was the dominant terminology (Crawford, Jackson, \& Godbey, 1991; Henderson, Stalnaker, \& Taylor, 1988; Jackson, 1990). The more inclusive term constraints is now preferred to barriers, because the latter fails to express the entire range of meaning of constraints in leisure activity participation (Jackson, 1988). Therefore, constraints have been more widely used than barriers and they represent not only the physical and external to the individual but also the internal and social (Crawford \& Godbey, 1987; Crawford \& Huston, 1993).

Crawford and Godbey (1987) insisted that constraints influence not only leisure activity participation but also acquisition of leisure preferences. They formulated a leisure constraints model in order to analyze leisure constraints scientifically, and the model has been elaborated upon continually with the addition of Jackson. Jackson (1988) explained that constraints are "best viewed as a subset of reasons for not engaging in particular behavior and leisure constraints represent a limit to obstructing leisure activity participation" (p. 207). Leisure constraints have been widely recognized as main factors that could prevent, reduce, or modify participation, or could negatively influence the quality of enjoyment of leisure activities (Shaw, 1999). The model of leisure constraints generated by Crawford, Jackson, and Godbey (1991) indicates that there are three dimensions of constraints impacting the https://scholarworks.umass.edu/refereed/ICHRIE_2011/Wednesday/6 


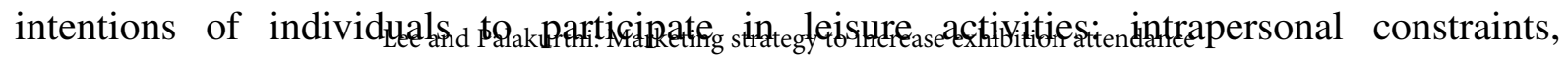
interpersonal constraints, and structural constraints. A more detailed explanation of these three dimensions of constraints follows.

\subsubsection{Intrapersonal Constraints}

Crawford and Godbey (1987) explained that intrapersonal constraints are individual psychological states (e.g., stress, anxiety, fatigue, depression), as well as religiosity, prior socialization into specific leisure activities, perceived self-skill, and subjective evaluations of the appropriateness and availability of various leisure activities. They identified that those attributes of intrapersonal constraints influence preference rather than interrupting between preference and participation and finally lead to nonparticipation. They also described the physical and mental conditions of individuals as intrapersonal constraints. Such constraints are relatively unstable and may change within a short period of time (Nyaupane \& Andereck, 2008).

Based on the above review of literature regarding intrapersonal constraints, the following research question was formulated here:

Research Question 1: Is there a relationship between demographic characteristics of exhibition attendees and the intrapersonal constraints perceived by them?

\subsubsection{Interpersonal Constraints}

Interpersonal constraints are the factors which influence relationships with one's family members, spouse, friends, colleagues and other companions whom could provide cooperative assistance as well as financial support (Crawford, Jackson, \& Godbey 1991). Individuals may experience an interpersonal constraint if their participation in leisure is influenced by other people, such as family, friends, or partners (Raymore, Godbey, Crawford, \& von Eye, 1993). Crawford, Jackson, and Godbey (1991) explained that constraints associated with family life cycle and marital relationships are characteristic of the 
interpersonal category. International CHRIE Conference-Refereed Track, Event 6 [2011]

Drawing on the above review of literature regarding interpersonal constraints, the following research question was raised as follows:

Research Question 2: Is there a relationship between demographic characteristics of exhibition attendees and the interpersonal constraints perceived by them?

\subsubsection{Structural Constraints}

Structural constraints are the interrupting factors between leisure preference and participation, including lack of time, money, opportunity, information and access, and influence of bad weather (Walker \& Virden, 2005). Other examples of structural constraints include family life-cycle stage, family financial resources, season, climate, the scheduling of work time, availability of opportunity and knowledge of such availability, and reference group attitudes concerning the appropriateness of certain activities (Crawford \& Godbey, 1987). Structural constraints also encompass lack of transportation, geographic distance, and overcrowding (Jackson, 2005; Walker \& Virden, 2005). Daniels, Drogin Rodgers, and Wiggins (2005) suggested that structural constraints are frequently found to be negotiated through intrapersonal or interpersonal constraints.

Based on the above review of literature regarding structural constraints, the following research question was derived below:

Research Question 3: Is there a relationship between demographic characteristics of exhibition attendees and the structural constraints perceived by them?

\section{METHODOLOGY}

A cross-sectional descriptive research design was employed in this study. The target population was customers who had an interest in exhibitions. The Institutional Review Board (IRB) approved the questionnaire prior to conducting the survey in Seoul, Gyeonggi, Incheon, 


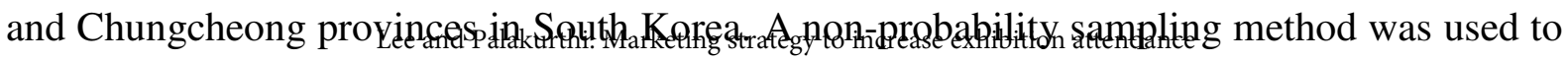
distribute the questionnaire to the target population in this study. Among non-probability sampling procedures, a convenience sampling method was employed to collect the data for this research. The questionnaire was distributed using a convenience sampling method to the public who visited or participated in the COEX (Convention \& Exhibition) center, which is the largest convention and exhibition center in Seoul. In addition, the KINTEX (Korea International Exhibition) center located in Goyang's West Ilsan District, and the residents who live in Seoul, Gyeonggi, Incheon, and Chungcheong provinces were also surveyed. A total of 500 people were invited to participate in the survey from August 22, 2009 through September 30, 2009 and a total of 419 usable surveys were collected. The response rate was 83.8 percent.

The questionnaire was comprised of two sections. The first section of the questionnaire measured the leisure constraints of the respondents. Nineteen questions were generated based on the literature review to measure the leisure constraints. The respondents were asked to respond to the questions using a five-point Likert type scale in the first and the second sections of the survey. The descriptors ranged from "strongly disagree (1)", “disagree (2)", "neutral (3)", "agree (4)”, and "strongly agree (5)”.

There were three subgroups of questions in the first section, one each for intrapersonal constraints, interpersonal constraints, and structural constraints. Six assessment items were used for intrapersonal constraints which included: (1) no interest (In the type of exhibition), (2) no concern (The exhibition is not related to their field of expertise), (3) not comfortable (Feel emotional or psychological embarrassment if attending such events e.g. men attending flower shows or women attending hardware tools shows), (4) fatigue (May not be able to attend the exhibition because of some personal or psychological limitations), (5) lack of information (The potential attendees had incomplete knowledge about the details of the exhibition such as date and time open to public, or the type of exhibitors showcasing their 


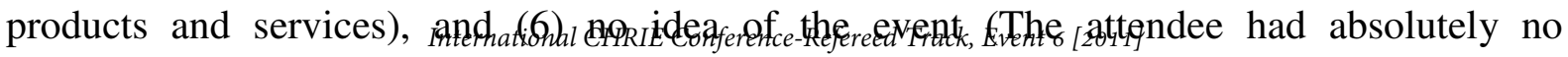
knowledge about the exhibitions). Four assessment items were used for interpersonal constraints which included: (1) companion's lack of interest (Although the attendee was interested in attending the exhibition, the attendee's companions, whoever it may be such as spouse, friends, siblings or parents, was not interested in attending the same exhibition), (2) lack of companions (Lack of availability of a friend or relative that could attend the exhibition), (3) companion's lack of time (Although the potential attendee was keenly interested in attending the exhibition, he/she could not do so because the companion could not attend because of a time or scheduling conflict), and (4) companion's lack of economic support (Although the potential attendee was keenly interested in attending the exhibition, he/she did not have the financial or other related resources to attend the event at the time it was available). Nine assessment items were used for structural constraints which included: (1) lack of time to participate (Although the potential attendee was keenly interested in attending the exhibition, he/she could not do so because of a time conflict), (2) other important work (Although the potential attendee was keenly interested in attending the exhibition, he/she could not do so because he/she had to attend to a higher priority task), (3) poor transportation service (Although the potential attendee was keenly interested in attending the exhibition, he/she could not do so because of lack of proper personal or public transportation to the venue from their place of residence), (4) expensive traffic expenses (Although the potential attendee was keenly interested in attending the exhibition, he/she could not do so because the expenses involved in travel to the venue were prohibitive), (5) expensive admission (Although the potential attendee was keenly interested in attending the exhibition, he/she could not do so because of the high entrance fees at the venue. The price-value relationship for attending the exhibition was not considered to be high), (6) lack of exciting programs (Although the potential attendee was keenly interested in attending the exhibition, he/she 


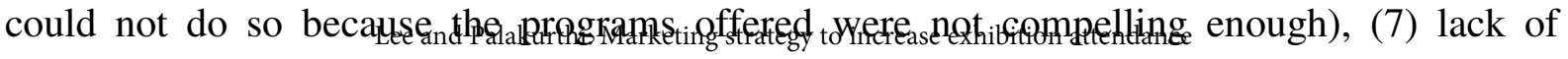
opportunity for special experiences (Although the potential attendee was keenly interested in attending the exhibition, he/she could not do so because the programs offered did not include anything new that the attendee could learn), (8) lack of entertaining facilities (Although the potential attendee was keenly interested in attending the exhibition, he/she could not do so because the venue lacked good facilities for entertainment such as stages and theaters for performances; restaurants and bars for dining; and retail outlets for shopping), and (9) bad weather conditions (Although the potential attendee was keenly interested in attending the exhibition, he/she could not do so because of a temporary weather condition). Table 3-1 shows the assessment items that former researchers have used for analyzing leisure constraints during the years 1951 to 2007.

Table 3-1. The History of the Assessment Items of Leisure Constraints

\begin{tabular}{|c|c|c|c|c|c|c|c|}
\hline & Assessment items & 1 & 2 & 3 & 4 & 5 & 6 \\
\hline $\begin{array}{c}\text { Intrapersonal } \\
\text { Constraints }\end{array}$ & $\begin{array}{l}\text { No interest } \\
\text { No concern } \\
\text { Not comfortable } \\
\text { Fatigue } \\
\text { Lack of information } \\
\text { No idea of the event }\end{array}$ & $\begin{array}{l} \\
\bullet \\
\bullet \\
\bullet\end{array}$ & $\bullet$ & $\begin{array}{l}\bullet \\
\bullet \\
\bullet \\
\bullet\end{array}$ & $\bullet$ & $\begin{array}{l} \\
\bullet\end{array}$ & $\begin{array}{l} \\
\bullet \\
\bullet\end{array}$ \\
\hline $\begin{array}{c}\text { Interpersonal } \\
\text { Constraints }\end{array}$ & $\begin{array}{l}\text { Companion's lack of interest } \\
\text { Lack of companions } \\
\text { Companion's lack of time } \\
\text { Companion's lack of economic support }\end{array}$ & & & • & $\bullet$ & $\bullet$ & $\begin{array}{l} \\
\bullet \\
\bullet \\
\bullet\end{array}$ \\
\hline $\begin{array}{c}\text { Structural } \\
\text { Constraints }\end{array}$ & $\begin{array}{l}\text { Lack of time to participate } \\
\text { Other important work } \\
\text { Poor transportation service } \\
\text { Expensive traffic expenses } \\
\text { Expensive admission } \\
\text { Lack of exciting programs } \\
\text { Lack of opportunities for special experience } \\
\text { Lack of entertaining facilities } \\
\text { Bad weather condition }\end{array}$ & $\begin{array}{l}\bullet \\
\bullet \\
\bullet\end{array}$ & $\begin{array}{l}\bullet \\
\bullet \\
\bullet \\
\bullet\end{array}$ & $\begin{array}{l}\bullet \\
\bullet \\
\bullet\end{array}$ & • & $\begin{array}{l}\bullet \\
\bullet \\
\bullet\end{array}$ & $\begin{array}{l}\bullet \\
\bullet \\
\bullet \\
\bullet \\
\bullet \\
\bullet\end{array}$ \\
\hline
\end{tabular}

1) Lewin, 1951; 2) McGuire, 1984; 3) Crawford \& Godbey, 1987; 4) Henderson, Stalnaker, \& Taylor, 1988; 5) Lee et al., 2004; 6) Lee, D. H., 2007

The second section was designed to solicit demographic information, which included gender, age, marital status, education, occupation, annual income, and place of residence. All the demographic information was measured using nominal scales. 


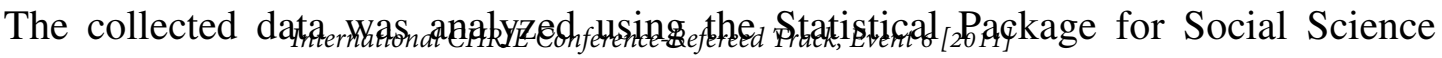
(SPSS) software. Statistical methods used to analyze the data included reliability analysis, principal components analysis, factor analysis, independent samples $t$-tests, paired samples $t$ tests, and analysis of variance (ANOVA). In order to achieve the objectives of this study, reliability analysis examined whether the survey questionnaire was reliable through the calculation of Cronbach's alpha statistic. In this study, 19 variables describing leisure constraints are a large number and some of them may be unrelated and uncorrelated. To summarize a large number of variables into a smaller number of variables, principle component analysis was utilized. Then, these variables were rotated on the varimax (variance maximization) rotation procedure in order to identify which variables are independent of each other and which variables are correlated. Factor analysis makes the factor loading of one variable close to 1 and the other close to 0 so that researchers can better understand which one is the uncorrelated factor and which one is not. In this study, factor analysis explored the underlying structures of the data through data reduction.

Independent samples $t$-tests were used for examining whether there were significant differences in leisure constraints among the levels of gender and marital status. In addition, analysis of variance (ANOVA) was used to determine whether there was a significant difference in leisure constraints among the levels of age, education, annual income, and place of residence.

\section{4. $\quad$ RESULTS}

\subsection{Demographic Profile of Respondents}

The demographic profile of the respondents is presented in Table 4-1. There were 181 (43.2\%) male respondents and $238(56.8 \%)$ female respondents. In terms of age, the main age group was $18-24$, representing $41.5 \%$ of the respondents. The other age groups were $25-34$ 


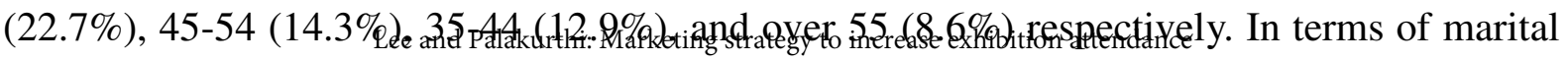
status, there were 155 (37\%) married respondents and 264 (63\%) unmarried respondents. More than two-thirds of the respondents attended or completed a college or university, accounting for $80.7 \%$ of the total respondents. Only $11.5 \%$ of the respondents attended or completed graduate school, while $7.9 \%$ of the respondents completed high school. As for occupation, the results indicated that $122(29.1 \%)$ of the respondents were students, 71 (16.9\%) were company employees, $56(13.4 \%)$ were business people, 54 (12.9\%) were professionals, $52(12.4 \%)$ were housewives, and 35 (8.4\%) were public service employees. In addition, $19(4.5 \%)$ respondents had a background in other business fields and $9(2.1 \%)$ respondents had a background in sales or service fields. In terms of annual income, $10.7 \%$ of respondents earned an annual income more than $\$ 80,000,11.2 \%$ between $\$ 60,000$ and $\$ 79,999,24.3 \%$ between $\$ 40,000$ and $\$ 59,999,33.4 \%$ between $\$ 20,000$ and $\$ 39,999$, and $20.3 \%$ less than $\$ 20,000$. More than half of the respondents were Seoul residents, accounting for $59.7 \%$ of the total respondents. Incheon residents accounted for $22.7 \%$ of the respondents, Gyeonggi residents, $14.1 \%$, and Chungcheong residents, $3.6 \%$.

Table 4-1. Demographic Profile of the Respondents $(N=419)$

\begin{tabular}{llll}
\hline Variables & Frequency & Percentage (\%) \\
\hline Age & & & \\
& $18-24$ & 174 & 21.5 \\
& $25-34$ & 95 & 12.9 \\
& $35-44$ & 54 & 14.3 \\
& $45-54$ & 60 & 8.6 \\
& Over 55 & 36 & 37.0 \\
Marital Status & & 63.0 \\
$\quad$ Married & 155 & \\
& Unmarried & 264 & 7.9 \\
Education & & 80.7 \\
& Completed High School & 33 & 11.5 \\
& Attended or Completed College or University & 338 & \\
$\quad$ Attended or Completed Graduate School & 48 & 59.7 \\
Place of Residence & & 22.7 \\
& Seoul & 250 & 14.1 \\
& Incheon & 95 & 3.6 \\
& Gyeonggi & 59 &
\end{tabular}

\subsection{Factor Analysis and Reliability Analysis}




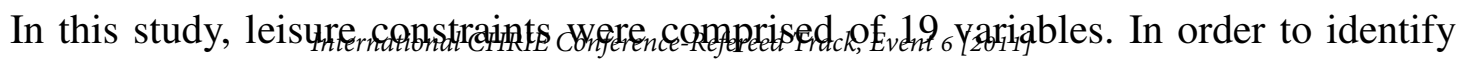
the key variables, principal components analysis was utilized using the varimax (variance maximization) rotation procedure. After analyzing the data by using principal component analysis with a varimax rotation, the 19 variables were reduced to three factors, which explained approximately $71 \%$ of the total variance. The communality of each variable was moderately acceptable, ranging from 0.428 to 0.839 (Table 4-2). If a score of Kaiser-MeyerOlkin Measure of Sampling Adequacy (KMO-MSA) is equal to or greater than 0.5, it indicates that the correlation matrix of variables is suitable for conducting factor analysis (Mantzopoulos, 1995). The KMO-MSA score for factor analysis for leisure constraints in this study was 0.786 , which confirmed that the correlation matrix of leisure constraints was suitable for conducting factor analysis. Bartlett's test of sphericity tests whether the strength of the relationship among variables is strong (Diekhoff, 1996). The Bartlett's test of sphericity $\chi^{2}$ for this study was 1858.908 at the observed significance level of alpha 0.001 , indicating a high level of strength among the variables (Table 4-2).

Table 4-2 summarizes the Cronbach's alpha measures of reliability. The Cronbach's alpha for intrapersonal constraints was 0.809 , for structural constraints was 0.878 , and for interpersonal constraints was 0.761 . These values indicate reasonable levels of internal consistency of measuring instruments in this study. Therefore, the results suggest that the variance of the original values was explained adequately by the three factors - intrapersonal constraints, interpersonal constraints, and structural constraints (Table 4-2).

Table 4-2. Factor Analysis and Reliability Analysis

\begin{tabular}{|c|c|c|c|c|}
\hline \multirow[t]{2}{*}{ Leisure Constraint Domains \& Items } & \multicolumn{3}{|c|}{ Factor loadings } & Communality \\
\hline & $\begin{array}{l}\text { Intrapersonal } \\
\text { Constraints }\end{array}$ & $\begin{array}{l}\text { Structural } \\
\text { Constraints }\end{array}$ & $\begin{array}{l}\text { Interpersonal } \\
\text { Constraints }\end{array}$ & \\
\hline \multicolumn{5}{|l|}{ Intrapersonal Constraints } \\
\hline Intra1 No concern & 0.899 & & & 0.826 \\
\hline Intra2 No interest & 0.888 & & & 0.795 \\
\hline Intra3 Not comfortable & 0.770 & & & 0.647 \\
\hline Intra4 Lack of information & 0.509 & & & 0.428 \\
\hline \multicolumn{5}{|l|}{ Structural Constraints } \\
\hline Stru1 Lack of opportunities & & 0.905 & & 0.839 \\
\hline \multicolumn{3}{|c|}{ https://scholarworks.umass.edu/refereed/ICHRIE_2011/Wednesday/6 } & & 14 \\
\hline
\end{tabular}


Stru2 Lack of entertaining facilities alakurthi: Marketing strategy to increase exhibition attendance 0.805

Stru3 Lack of exciting programs

Interpersonal Constraints

Inter1 Companion's lack of time

Inter2 Companion's lack of economic support

\begin{tabular}{l|l}
0.842 & 0.748
\end{tabular}

Inter3 Lack of companions

Total variance explained

$\begin{array}{lllll}\% \text { of variance explained } & 25.420 & 24.334 & 21.471 & 71.225 \\ \text { Cronbach's Alpha } & 0.809 & 0.878 & 0.761\end{array}$

$\begin{array}{llll}\text { Eigenvalue } & 2.542 & 2.433 & 2.471\end{array}$

Note: Kaiser-Meyer-Olkin Measure of Sampling Adequacy (KMO-MSA): 0.786;

Bartlett's Test of Sphericity, $\chi^{2}=1858.908$, significance at $p<0.001$.

\subsection{Independent Samples t-tests}

An Independent-samples $t$-test was conducted to determine if there was a significant difference in the mean scores for the degree of leisure constraints between married and unmarried respondents. In terms of intrapersonal constraints and structural constraints, there was no significant difference in the mean for married and unmarried respondents. However, in terms of interpersonal constraints, there was a significant difference in the means for married and unmarried respondents. Specifically, married respondents $(\mathrm{M}=2.97 ; \mathrm{SD}=0.99)$ had a higher mean score than unmarried respondents $(\mathrm{M}=2.66 ; \mathrm{SD}=1.02)$ for the item "companion's lack of economic support" [t(417) $=3.02 ; p<0.01]$ (Table 4-3).

Table 4-3. Significant Difference in the Mean Scores for the Degree of Leisure Constraints According to Marital Status

\begin{tabular}{|c|c|c|c|}
\hline Leisure Constraint Domains \& Items & $\begin{array}{l}\text { Married } \\
\mathrm{M}(\mathrm{SD})\end{array}$ & $\begin{array}{l}\text { Unmarried } \\
\mathrm{M}(\mathrm{SD})\end{array}$ & $t$-value \\
\hline \multicolumn{4}{|l|}{ Intrapersonal Constraints } \\
\hline No concern & $2.41(0.92)$ & $2.49(0.98)$ & 0.30 \\
\hline No interest & $2.49(0.94)$ & $2.46(1.04)$ & 0.27 \\
\hline Not comfortable & $2.49(0.92)$ & $2.30(0.98)$ & 1.91 \\
\hline Lack of information & $3.30(0.97)$ & $3.16(1.06)$ & 1.40 \\
\hline \multicolumn{4}{|l|}{ Interpersonal Constraints } \\
\hline Companion's lack of time & $3.14(0.98)$ & $3.06(0.97)$ & 0.88 \\
\hline Companion's lack of economic support & $2.97(0.99)$ & $2.66(1.02)$ & $3.02 * *$ \\
\hline Lack of companions & $3.00(0.94)$ & $3.09(1.06)$ & -0.81 \\
\hline \multicolumn{4}{|l|}{ Structural Constraints } \\
\hline Lack of opportunities & $3.40(0.92)$ & $3.40(1.00)$ & -0.05 \\
\hline Lack of entertaining facilities & $3.27(1.01)$ & $3.38(0.97)$ & -1.04 \\
\hline Lack of exciting programs & $3.30(0.95)$ & $3.47(0.95)$ & -1.69 \\
\hline
\end{tabular}




\subsection{Analysis of Variance International CHRIE Conference-Refereed Track, Event 6 [2011]}

Analysis of variance (ANOVA) was conducted to examine whether there was any significant difference in the mean scores of the different age groups among the leisure constraints. In terms of intrapersonal constraints, the results of the ANOVA test indicated that there were significant mean differences for the items "not comfortable" $[\mathrm{F}(4,414)=3.62$; $p=0.006]$ and "lack of information" $[\mathrm{F}(4,414)=2.43 ; p=0.047]$. Duncan's post hoc test was used to discover the significant mean difference among different age groups. For the item, "not comfortable", the four age groups: $25-34(\mathrm{M}=2.4 ; \mathrm{SD}=0.9), 35-44(\mathrm{M}=2.5 ; \mathrm{SD}=0.9)$, 45-54 $(\mathrm{M}=2.5 ; \mathrm{SD}=0.9)$, and over $55(\mathrm{M}=2.5 ; \mathrm{SD}=0.9)$, had higher mean scores than the youngest age group, $18-24(\mathrm{M}=2.1 ; \mathrm{SD}=0.9)$. For the item, "lack of information", the age group 35-44 $(\mathrm{M}=3.5 ; \mathrm{SD}=0.8)$ had a higher mean score than the other age groups (Table 44).

In terms of interpersonal constraints, the results of the ANOVA test indicated that there were significant mean differences for the items "companion's lack of time" $[\mathrm{F}(4,414)=$ $3.27 ; p=0.012]$ and "companion's lack of economic support" $[\mathrm{F}(4,414)=3.49 ; p=0.008]$. Duncan's post hoc test revealed that two age groups, 35-44 $(\mathrm{M}=3.4 ; \mathrm{SD}=0.9)$ and $45-54(\mathrm{M}$ $=3.3 ; \mathrm{SD}=0.9)$, had higher mean scores than the other groups for the item "companion's lack of time". For the item, "companion's lack of economic support", the age groups, 35-44 $(\mathrm{M}=3.0 ; \mathrm{SD}=0.9)$ and 45-54 $(\mathrm{M}=3.1 ; \mathrm{SD}=1.0)$, had higher mean scores than the other age groups. In terms of structural constraints, there was no significant mean difference among the different age groups (Table 4-4).

Table 4-4. Significant Difference in the Mean Scores for the Degree of Leisure Constraints According to Age

\begin{tabular}{|c|c|c|c|c|c|c|}
\hline Leisure Constraint Domains \& Items & $\begin{array}{l}18-24 \\
\mathrm{M}(\mathrm{SD})\end{array}$ & $\begin{array}{l}25-34 \\
M(S D)\end{array}$ & $\begin{array}{l}35-44 \\
M(S D)\end{array}$ & $\begin{array}{l}45-54 \\
\mathrm{M}(\mathrm{SD})\end{array}$ & $\begin{array}{l}\text { Over 55 } \\
\mathrm{M}(\mathrm{SD})\end{array}$ & F-value \\
\hline \multicolumn{7}{|l|}{ Intrapersonal Constraints } \\
\hline No concern & $2.2(0.9)$ & $2.5(0.9)$ & $2.5(0.9)$ & $2.4(0.9)$ & $2.5(1.0)$ & 1.80 \\
\hline No interest & $2.3(1.0)$ & $2.4(0.9)$ & $2.7(0.9)$ & $2.5(0.9)$ & $2.6(0.9)$ & 1.79 \\
\hline
\end{tabular}




\begin{tabular}{|c|c|c|c|c|c|c|}
\hline $\begin{array}{l}\text { Not comfortable } \\
\text { Lack of information }\end{array}$ & 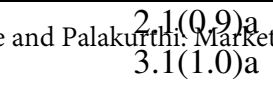 & $\begin{array}{l}24(0.9) b_{\text {bin }} \\
\text { g strategy to in } \\
3.0(1.0) a\end{array}$ & 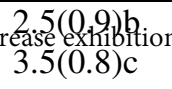 & $\begin{array}{l}2.5(0.9) b \\
\text { attendance } \\
3.2(1.0) \mathrm{b}\end{array}$ & $\begin{array}{l}2.5(0.9) \mathrm{b} \\
3.2(1.0) \mathrm{b}\end{array}$ & $\begin{array}{l}3.62 * * \\
2.43^{*}\end{array}$ \\
\hline \multicolumn{7}{|l|}{ Interpersonal Constraints } \\
\hline Companion's lack of time & $3.0(0.9) \mathrm{b}$ & $3.0(0.9) \mathrm{b}$ & $3.4(0.9) \mathrm{c}$ & $3.3(0.9) \mathrm{c}$ & $2.8(1.1) \mathrm{a}$ & $3.275^{*}$ \\
\hline $\begin{array}{l}\text { Companion's lack of ec } \\
\text { support }\end{array}$ & economic2.6(1.0)a & 2.7(0.9)ab & $3.0(0.9) \mathrm{c}$ & $3.1(1.0) \mathrm{c}$ & 2.7(1.1)ab & $3.491 * *$ \\
\hline Lack of companions & $3.0(1.0)$ & $3.0(1.0)$ & $3.1(1.0)$ & $3.1(0.8)$ & $2.7(0.9)$ & 1.274 \\
\hline \multicolumn{7}{|l|}{ Structural Constraints } \\
\hline Lack of opportunities & $3.3(1.0)$ & $3.4(0.9)$ & $3.6(0.8)$ & $3.3(0.8)$ & $3.2(0.9)$ & 0.949 \\
\hline Lack of entertaining facilities & $3.3(0.9)$ & $3.3(1.0)$ & $3.5(0.7)$ & $3.1(1.0)$ & $3.2(1.0)$ & 1.464 \\
\hline Lack of exciting programs & $3.4(0.9)$ & $3.3(0.9)$ & $3.5(0.8)$ & $3.2(1.0)$ & $3.2(0.9)$ & 1.603 \\
\hline
\end{tabular}

$* p<0.05, * * p<0.01, * * * p<0.001$

Scale: 1-Strongly Disagree, 2-Disagree, 3-Neutral, 4-Agree, 5-Strongly Agree

Analysis of variance (ANOVA) was conducted to determine whether there was any significant difference in the mean scores of the different levels of education among the leisure constraints. In terms of intrapersonal constraints, the results of the ANOVA test indicated that there were significant mean differences for the items "no concern" $[\mathrm{F}(2,416)=6.755 ; p=$ $0.001]$ and "no interest" $[\mathrm{F}(2,416)=8.197 ; p=0.001]$. Duncan's post hoc test revealed that respondents who completed high school $(\mathrm{M}=2.96 ; \mathrm{SD}=0.76)$ had a higher mean score than the other categories for the item "no concern". Duncan's post hoc test also revealed that respondents who completed high school $(\mathrm{M}=3.12$; $\mathrm{SD}=0.89)$ had a higher mean score than the other categories for the item "no interest". In terms of interpersonal and structural constraints, there was no significant difference in the means of the different levels of education (Table 4-5).

Table 4-5. Significant Difference in the Mean Scores for the Degree of Leisure Constraints According to Education

\begin{tabular}{|c|c|c|c|c|}
\hline \multirow[t]{2}{*}{ Leisure Constraint Domains \& Items } & $\begin{array}{l}\text { Completed } \\
\text { High School }\end{array}$ & $\begin{array}{l}\text { Attended } \\
\text { or Completed } \\
\text { College or } \\
\text { University }\end{array}$ & $\begin{array}{l}\text { Attended } \\
\text { or Completed } \\
\text { Graduate } \\
\text { School }\end{array}$ & F-value \\
\hline & $\mathrm{M}(\mathrm{SD})$ & $\mathrm{M}(\mathrm{SD})$ & $\mathrm{M}(\mathrm{SD})$ & \\
\hline \multicolumn{5}{|l|}{ Intrapersonal Constraints } \\
\hline No concern & $2.96(0.76) \mathrm{a}$ & $2.36(0.96) b$ & $2.25(0.91) b$ & $6.755^{* * *} *$ \\
\hline No interest & $3.12(0.89) \mathrm{a}$ & $2.43(1.00) b$ & $2.27(0.98) b$ & $8.197 * * *$ \\
\hline Not comfortable & $2.63(0.69)$ & $2.35(0.98)$ & $2.31(0.99)$ & 1.368 \\
\hline Lack of information & $3.15(1.17)$ & $3.18(1.02)$ & $3.50(0.96)$ & 2.051 \\
\hline
\end{tabular}




\begin{tabular}{lcccc}
\hline Interpersonal Constraints & International CHRIE Conference-Refereed Track, Event 6 [2011] & \\
$\quad$ & $2.96(0.76)$ & $3.06(0.98)$ & $3.35(0.99)$ & 2.097 \\
Companion's lack of time & $3.03(0.84)$ & $2.73(1.03)$ & $2.91(1.04)$ & 1.756 \\
Companion's lack of economic support & $3.21(0.96)$ & $3.03(1.04)$ & $3.12(0.86)$ & 0.563 \\
Lack of companions & & & & \\
& & & & \\
Structural Constraints & $3.36(0.92)$ & $3.38(0.98)$ & $3.54(0.89)$ & 0.554 \\
$\quad$ Lack of opportunities & $3.36(1.14)$ & $3.33(0.98)$ & $3.37(0.98)$ & 0.037 \\
Lack of entertaining facilities & $3.36(1.02)$ & $3.41(0.94)$ & $3.41(1.00)$ & 0.047 \\
$\quad$ Lack of exciting programs & & & & \\
\hline
\end{tabular}

$* p<0.05, * * p<0.01, * * * p<0.001$

Scale: 1-Strongly Disagree, 2-Disagree, 3-Neutral, 4-Agree, 5-Strongly Agree

Analysis of variance (ANOVA) was conducted to determine whether there was any significant difference in the mean scores of the degree of constraints among the different levels of place of residence. In terms of intrapersonal constraints, the results of the ANOVA test indicated that there were significant mean differences for the items "no concern" $[\mathrm{F}(3$, $415)=3.744 ; p=0.011]$, "no interest" $[\mathrm{F}(3,415)=3.978 ; p=0.008]$, and "not comfortable" $[\mathrm{F}(3,415)=3.978 ; p=0.008]$. Duncan's post hoc test was used to discover the significant mean difference among the different levels of place of residence. The respondents who lived in Chungcheong province $(\mathrm{M}=2.7 ; \mathrm{SD}=0.7)$ had the highest mean score than the other categories for the item "no concern". In addition, the respondents who lived in Chungcheong province $(\mathrm{M}=2.8 ; \mathrm{SD}=0.8)$ had the highest mean score than the other categories for the item "no interest". For the item, "not comfortable", the respondents who lived in Gyeonggi province $(\mathrm{M}=2.6 ; \mathrm{SD}=1.0)$ had the highest mean score than the other categories. In terms of interpersonal and structural constraints, there was no significant difference in the means of the different levels of place of residence (Table 4-6).

Table 4-6. Significant Difference in the Mean Scores for the Degree of Leisure Constraints According to Place of Residence

\begin{tabular}{llllll}
\hline Leisure Constraint Domains \& Items & $\begin{array}{l}\text { Seoul } \\
\mathrm{M}(\mathrm{SD})\end{array}$ & $\begin{array}{l}\text { Incheon } \\
\mathrm{M}(\mathrm{SD})\end{array}$ & $\begin{array}{l}\text { Gyeonggi } \\
\mathrm{M}(\mathrm{SD})\end{array}$ & $\begin{array}{l}\text { Chungcheong } \\
\mathrm{M}(\mathrm{SD})\end{array}$ & F-value \\
\hline Intrapersonal Constraints & & & & & \\
$\quad$ No concern & $2.4(1.0) \mathrm{ab}$ & $2.1(0.8) \mathrm{a}$ & $2.5(0.9) \mathrm{b}$ & $2.7(0.7) \mathrm{b}$ & $3.744^{*}$ \\
$\quad$ No interest & $2.5(1.0) \mathrm{ab}$ & $2.1(0.9) \mathrm{a}$ & $2.6(0.9) \mathrm{ab}$ & $2.8(0.8) \mathrm{b}$ & $3.978^{* *}$ \\
$\quad$ Not comfortable & $2.4(0.9) \mathrm{ab}$ & $2.1(0.8) \mathrm{a}$ & $2.6(1.0) \mathrm{b}$ & $2.4(0.8) \mathrm{ab}$ & $3.978^{* *}$ \\
Lack of information & $3.2(1.0)$ & $3.2(1.0)$ & $3.2(1.0)$ & $2.9(0.8)$ & 1.312
\end{tabular}




\begin{tabular}{|c|c|c|c|c|c|}
\hline \multicolumn{6}{|c|}{ Interpersonal Constraints Lee and Palakurthi: Marketing strategy to increase exhibition attendance } \\
\hline Companion's lack of time & $3.1(1.0)$ & $2.9(0.9)$ & $2.9(0.9)$ & $3.4(0.9)$ & 2.256 \\
\hline Companion's lack of economic support & $2.8(1.0)$ & $2.6(1.0)$ & $2.7(0.9)$ & $2.9(1.0)$ & 0.722 \\
\hline Lack of companions & $3.1(1.0)$ & $2.9(1.1)$ & $2.8(0.8)$ & $3.2(0.7)$ & 2.014 \\
\hline \multicolumn{6}{|l|}{ Structural Constraints } \\
\hline Lack of opportunities & $3.4(0.9)$ & $3.4(1.0)$ & $3.3(0.8)$ & $3.1(0.8)$ & 0.728 \\
\hline Lack of entertaining facilities & $3.3(1.0)$ & $3.3(0.9)$ & $3.3(0.8)$ & $3.0(0.7)$ & 0.458 \\
\hline Lack of exciting programs & $3.4(0.9)$ & $3.3(1.0)$ & $3.3(0.7)$ & $3.2(1.0)$ & 0.452 \\
\hline
\end{tabular}

$* p<0.05, * * p<0.01, * * * p<0.001$

Scale: 1-Strongly Disagree, 2-Disagree, 3-Neutral, 4-Agree, 5-Strongly Agree

\section{CONCLUSIONS AND IMPLICATIONS}

Traditionally, exhibitions have been regarded as a tactical marketing tool and an effective marketing pathway not only to increase business interactions and human activities but also to enhance communication with exhibition attendees. The number of exhibitions has quickly increased worldwide because of these business and social benefits. However, the increasing number of exhibition centers does not guarantee the growth of the exhibition industry.

The primary purpose of exhibition centers has been to use them as a place to encourage business interactions. As the size and scope of exhibition centers is getting larger and more leisure activities are added, not only do business people but also the general public expect to experience the gamut of leisure activities while attending exhibitions. However, some exhibitions are crowded and some exhibitions are less attended, irrespective to their popularity. The author of this study surmised that there were specific constraints which prevent customers from attending exhibitions because of various reasons. In order to confirm these reasons for impediment to attending exhibitions, Leisure Constraints Theory was considered to be an appropriate model to use. Nineteen leisure constraints explored from the review of literature were examined. To reiterate, exhibition attendees significantly considered four intrapersonal constraints, three interpersonal constraints, and three structural constraints. Intrapersonal constraints were comprised of "no concern", "no interest", "not comfortable", 


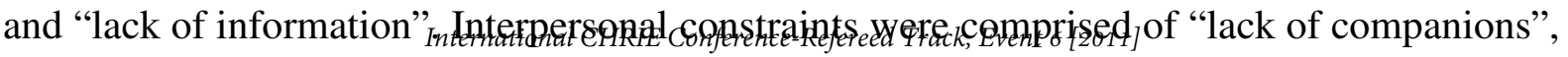
“companion's lack of time”, and “companions' lack of economic support". Structural constraints were comprised of "lack of exciting programs", "lack of opportunities for special experiences", and "lack of entertaining facilities".

Some important implications that results from the conclusions of this study are described below. Married attendees may have to make a higher financial/economic commitment than unmarried attendees, thereby forcing them to show a higher level of interpersonal constraint. This conclusion implies that exhibition marketing also needs to pay attention to the marital status of the potential attendees. There is a difference in how married or unmarried attendees perceive the interpersonal constrains. Therefore, marketing efforts must be made to reduce the perceived interpersonal constraints of married attendees who may bring their families along to the exhibitions. Therefore, family marketing campaigns offering group discounts or free tickets may help exhibition attendees who may lack the economic support from their companions. In addition, group package tour to exhibitions may reduce economic burdens in attending exhibitions.

It is interesting that attendees in the age group 35- 44 years showed the most significant intrapersonal and interpersonal constraints with regards to attending exhibitions. Such behavior may be explained by the expected lack of time and resources available to this busy demographic group that is in the prime of their lives. Such a busy life may not allow them to have enough time to explore all available options for attending exhibitions. In order to attract this busy demographic group, exhibition promoters must entertain alternate or additional times of operations to make it more viable for them to attend. For example, the age group 35-44 years may not have enough time to attend exhibitions during the regular work hours, however, if the exhibition is open till 10 p.m. or midnight, they may be able to attend and participate in all the leisure activities. 


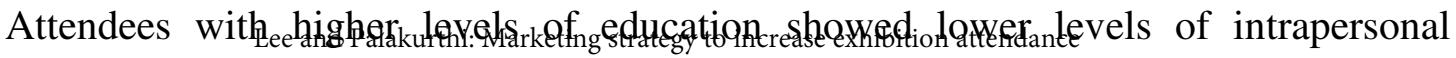
constraints with regards to attending exhibitions. This may be true since many other aspects in life are also linked with the education level such as, income, occupation, etc. Therefore, all such other factors many also be confounding the issues and preventing the attendees with lower levels of education from attending exhibitions. This conclusion implies that exhibition marketers should be more prudent and precisely target groups of potential attendees based on their specialized interests which in turn may be dependent on their educational levels. For example, more professional exhibitions should be created to increase the number of attendees who have higher levels of education. In addition, attendees with lower levels of education may be enticed to specific shows by informing them about the utility of such shows since they can enhance the depth of knowledge in their specialized field. Exhibition managers need to strengthen marketing campaigns to encourage attendance.

Residents living further away show more intrapersonal constrains for attending exhibitions compared to residents living closer to the exhibition venues. The distance of the exhibition center from place of residence is an impediment to attending exhibitions. Exhibition managers need to inform far-distant residents of the benefits which may be gained from attending exhibitions via email or other communication tools. More specific campaigns that target residents from distant areas may need to be conducted. For example, an entrance fee that is based on a "tier-system" hinged on the distance traveled by the attendee might do the trick. Attendees coming from further away may get a deep discount for their effort.

The findings of this study give exhibition planners, organizers, managers, and researchers, useful information for discovering marketing strategies in order to control and eliminate specific constraints which prevent customers from attending exhibitions. The study's implications suggest that exhibition marketers must pay more attention to understand 


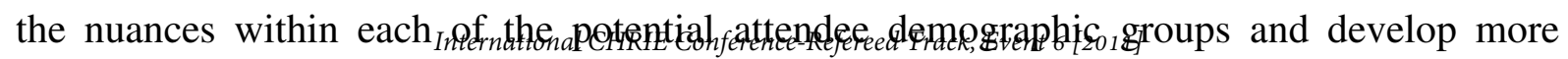
targeted campaigns.

\section{LIMITATIONS}

The limitations in this study are mostly related to sampling and data collection methodologies. The data collected for this research was from South Korean consumers attending exhibitions and visiting exhibition centers during a specific and limited time period in 2009. This limits the generalization of the results obtained. Many cultural and idiosyncratic differences exist between South Korean exhibition attendees and other such attendees in the Western world. South Korean exhibition attendees may be more inclined to attend such events because of the newness of such massive events in the country as a consequence of the booming economy in South Korea. Therefore, South Korean attendees may be more inclined to attend such events than people in the Western world. On another note, South Korean attendees also expect to find entertainment with information while they attend exhibitions whereas such a combination may not necessarily be required in the Western world. Such subtle differences may influence some of the reasons why people attend exhibitions in both the regions.

\section{REFERENCES}

Barreyre, P., \& Letrein, D. (1990). Promotional communication towards suppliers. Proceedings of the 6th industrial marketing and purchasing conference (pp. 106-116). Milan: Universita Bocconi.

Bello, D. C. (1992). Industrial buyer behavior at trade shows: Implications for selling effectiveness. Journal of Business Research, 25, 59-80.

Blythe, J. (2002). Using trade fairs in key account management. Industrial Marketing Management, 31, 627-635.

Bonoma, T. V. (1983). Get more out of your trade shows. Harvard Business Review, 61, https://scholarworks.umass.edu/refereed/ICHRIE_2011/Wednesday/6 
71-83.

Crawford, D. W., \& Godbey, G. (1987). Reconceptualizing barriers to family leisure. Leisure Sciences, 9, 119-127.

Crawford, D. W., \& Huston, T. L. (1993). The impact of the transition to parenthood on marital leisure. Personality and Social-Psychology Bulletin, 19, 39-46.

Crawford, D. W., Jackson, E. L., \& Godbey, G. (1991). A hierarchical model of leisure constraints. Leisure Sciences, 13, 309-320.

Daniels, M. J., Drogin Rodgers, E. B., \& Wiggins, B. P. (2005). Travel Tales: An interpretive analysis of constraints and negotiations to pleasure travel as experienced by persons with physical disabilities. Tourism Management, 26(6), 919.

Godar, S., \& O'Connor, H. (2001). Same time next year - buyer trade show motives. Industrial Marketing Management, 30(1), 77-86.

Henderson, K. A., Stalnaker, D., \& Taylor, G. (1988). The relationship between barriers to recreation and gender-role personality traits for women. Journal of Leisure Research, 20, 69-80.

Herbig, P., O’Hara, B., \& Palumbo, F. (1994). Measuring trade show effectiveness: An effective exercise? Industrial Marketing Management, 23, 165-170.

Jackson, E. L. (1988). Leisure constraints: A survey of past research. Leisure Sciences, 10, 203-215.

Jackson, E. L. (1990). Trends in leisure preference: Alternative constraints-related explanations. Journal of Applied Recreation Research, 15, 129-145.

Jackson, E. L. (1991). Research update: Leisure constraints. Parks and Recreation, 73, 18-23.

Jackson, E. L. (2005). Constraints to leisure. State College, PA: Venture.

Kaminer, D. A. (1992). Trade shows: How big business does bigger business. Business Marketing, 77(Nov.): A2-A4.

Kijewski, V., Yoon, E., \& Young, G. (1993). How exhibitors select trade shows. Industrial Marketing Management, 22(4), 287-298.

Kim, S. S., Chon, K., \& Chung, K. Y. (2003). Convention industry in South Korea: An economic impact analysis. Tourism Management, 24, 533-541.

Kim, S. S., Sun, H., \& Ap, J. (2008). Is there competition in the exhibition market in Asia? Analysis of the positioning of major Asian exhibition host cities. Asia Pacific journal of Tourism Research, 13(3). 205-215. 


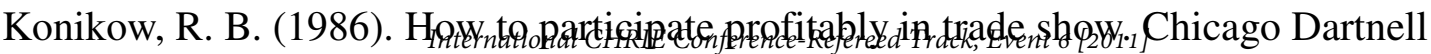
Corp. p. 129.

Kotler, P. (1971). Marketing management: Analysis, planning, and control. NJ: PrenticeHall.

Kotler, P., \& Levy, S. J. (1969). Broadening the concept of marketing. Journal of Marketing, 33(1), 10-15.

Lee, D. H. (2007). Exhibition Participation and Constraints. Unpublished thesis. Hanyang International Graduate School, Seoul, 1-4.

Lee, H., Jeong, C., Jeong, R. S., Lee, S. K., \& Jeong, W. C. (2004). Structural equation model of leisure activities and constraints. Tourism and Leisure Research, 16(2), 2948.

Lewin, K. (1951). Field theory in social science. Harper and Row. New York.

Lilien, G. L. (1983). A descriptive model of the trade-show budgeting decision process. Industrial Marketing Management, 12(1), 25-29.

Ling-Yee, L. (2006). Relationship learning at trade shows: Its antecedents and consequences. Industrial Marketing Management, 35(2), 166-177.

Ling-Yee, L. (2007). Marketing resources and performance of exhibitor firms in trade show: A contingent resource perspective. Industrial Marketing Management, 36(3), 360-370.

Luckhurst, K. W. (1951). The story of exhibitions. London, UK: The Studio Publications.

McCabe, V. S. (2001). Career paths and labor mobility in the convention and exhibition industry in Eastern Australia: Results from a preliminary study. International Journal of Tourism Research, 3, 493-499.

McGuire, F. A. (1984). A factor analytic study of leisure constraints in advanced adulthood. Leisure Sciences, 6, 323-326.

McLean, K. (1994). Planning for people in museum exhibition. Association of Science Technology Center, 15-16.

Morrow, S. L. (2001). The art of the show. (2nd ed.). Dallas, TX: IAEM Education Foundation.

Nyaupane, G. P., \& Andereck, K. L. (2008). Understanding travel constraints: Application and extension of a leisure constraints model. Journal of Travel Research, 46(4), 433-439.

Raymore, L, Godbey, G., Crawford, D., \& von Eye, A. (1993). Nature and process of leisure constraints: An empirical test. Leisure Sciences, 15, 99-113. 
Lee and Palakurthi: Marketing strategy to increase exhibition attendance

Reeder, C. W., \& Linkowski, D. C. (1976). An institute on attitudinal, legal, and leisure barriers to the disabled. Rehabilitation Counseling Bulletin, 20, 76-79.

Rice, G., \& Almossawi, M. (2002). A study of exhibitor firms at an Arabian gulf trade show: Goals, selection criteria and perceived problems. Journal of Global Marketing, $15(3 / 4)$.

Robbe, D. (2000). Expositions and trade shows: John Wiley \& Sons Inc.

Rogers, T. (2003). Conferences and conventions: A global industry ( $1^{\text {st }}$ ed.). Oxford, United Kingdom: Butterworth-Heinemann.

Rosson, P. J. \& Seringhaus F. H. R. (1995). Visitor and exhibitor interaction at industrial trade fairs. Journal of Business Research, 32(1), 81-90.

Searle, M. S., \& Jackson, E. L. (1985). Recreation non-participation and barriers to participation: Considerations for management of recreation delivery systems. Journal of Park and Recreation Administration, 3, 23-36.

Shaw, S. M. (1999). Gender and leisure, in Leisure Studies: Prospects for the 21st Century (edited by E. Jackson and T. Burton), Venture Press, State College, PA, pp. 299-321.

Shoham, A. (1992). Selecting and evaluating trade shows. Industrial Marketing Management, 21(4), 335-341.

Smith, T. M., Hama, K., \& Smith, P. M. (2003). The effect of successful trade show attendance on future show interest: Exploring Japanese attendee perspectives of domestic and offshore international events. Journal of Business and Industrial Marketing, 18(4/5), 403-418.

Thomas, L. G. (1956). Leisure pursuits by socio-economic strata. Journal of Educational Sociology, 29, 367-377.

Walker, G., \& Virden, R. (2005). Constraints on outdoor recreation: In constraints to leisure. Edited by E. L. Jackson. State College, PA: Venture, pp. 201-19.

Witt, P. \& Goodale, T. (1981). The relationship between barriers to leisure enjoyment and family stages. Leisure Sciences, 4, 29-49.

Wood, V. (1971). Age-appropriate behavior for older people. Gerontologist, 11, 74-78.

Yoo, J., \& Weber, K. (2005). Progress in convention tourism research. Journal of Hospitality \& Tourism Research, 29, 194-222. 